\title{
Strong connections, loose coupling: the influence of the Bering Sea ecosystem on commercial fisheries and subsistence harvests in Alaska
}

\author{
Alan C. Haynie $^{1}$ and Henry P. Huntington ${ }^{2}$
}

\begin{abstract}
Human-environment connections are the subject of much study, and the details of those connections are crucial factors in effective environmental management. In a large, interdisciplinary study of the eastern Bering Sea ecosystem involving disciplines from physical oceanography to anthropology, one of the research teams examined commercial fisheries and another looked at subsistence harvests by Alaska Natives. Commercial fisheries and subsistence harvests are extensive, demonstrating strong connections between the ecosystem and the humans who use it. At the same time, however, both research teams concluded that the influence of ecosystem conditions on the outcomes of human activities was weaker than anticipated. Likely explanations of this apparently loose coupling include the ability of fishers and hunters to adjust to variable conditions, and the role of social systems and management in moderating the direct effects of changes in the ecosystem. We propose a new conceptual model for future studies that incorporates a greater range of social factors and their dynamics, in addition to similarly detailed examinations of the ecosystem itself.
\end{abstract}

Key Words: Bering Sea; commercial fisheries; ecosystem studies; human-environment connections; subsistence

\section{INTRODUCTION}

Connections between humans and the natural environment are the subject of much attention (e.g., the International Human Dimensions Program: http://www.ihdp.unu.edu, the Intergovernmental Platform on Biodiversity and Ecosystem Services: http://www. ipbes.net). The inclusion of social science topics and practitioners in ecosystem research programs recognizes the importance of societal factors in shaping human interactions with ecosystems and the ecosystems themselves (e.g., Levin et al. 2009, 2014, Kittinger et al. 2012, Loomis and Paterson 2014). These efforts are based on the premise that natural-social connections exist, that humans and the environment affect one another, and that these interactions are substantial enough to cause variability and change in both realms (e.g., Alberti et al. 2011). Furthermore, understanding the human-environment connection is essential for effective environmental management because management depends largely on controlling human activity to achieve desired social and ecological goals.

Much work has been done on such questions, for example, in the area of social-ecological systems (SESs; e.g., Bodin and Tengö 2012). A main purpose of the development of SES frameworks is to organize thinking about a particular system to understand better how the system's components are related to one another and how those relationships together determine the overall wellbeing or resilience of the system (Folke et al. 2010, McGinnis and Ostrom 2014). This type of thinking, under various labels, has been applied to activities such as fishing to examine the roles of different factors influencing fishers' behavior and outcomes (e.g., Mahon et al. 2008, Rochet et al. 2012, Hentati-Sundberg et al. 2015). A central consideration in the interactions of SES components is that of scale, in time and space (e.g., Cumming et al. 2006, Perry et al. 2011, Crona et al. 2016), because influences and relationships vary with distance and with rate of change. The scope and complexity of the model of an SES will be determined by the questions being asked and will start with a set of expectations about how its components are connected (e.g., Bodin and Tengö 2012, McGinnis and Ostrom 2014). Putting these concepts into practice, however, may be confounded by socialecological systems that do not perform as anticipated.

Here, the point of departure is our experience in studying humanecosystem interactions as part of the large, interdisciplinary Bering Sea Project (Wiese et al. 2012). One premise of the study was that human activities would respond clearly and directly to changes in the physical and biological aspects of the ecosystem. This expectation was based on other high-latitude systems where human outcomes are indeed tightly coupled to ecosystem conditions (e.g., Hamilton et al. 2003, 2004) and to similar drivers of demographic and other changes to the human system (e.g., Huntington et al. 2007, Voinov et al. 2004). Our work in the two components of the project, however, led us more or less independently to the understanding that the ways in which ecosystem change influences humans in the Bering Sea are strongly attenuated by social dynamics. As will be explained further, we distinguish between connections (by which humans and the ecosystem interact, for example, through fisheries) and coupling (by which changes in the ecosystem or in human activity directly and unavoidably produce a corresponding change in the other). Subsequent to the work on our respective components, we together explored the implications for research and for management of finding the expected strong connections but unexpectedly loose coupling between the ecosystem and humans in the Bering Sea.

Our analysis draws on the results of two components of the Bering Sea Project. The commercial fisheries component analyzed how the pollock (now renamed as Gadus chalcogrammus) and Pacific cod (Gadus macrocephalus) fisheries have adjusted to environmental variation, as well as how management, markets, and biological conditions have all affected fisher behavior (Haynie and Pfeiffer 2012, 2013, Pfeiffer and Haynie 2012). The local and 
traditional knowledge (LTK; Berkes 1999) component documented Alaska Native subsistence practices in five villages in the eastern Bering Sea alongside hunters' and fishers' knowledge of the ecosystem (Fig. 1; Fall et al. 2013, FienupRiordan et al. 2013, Huntington et al. 2013a,b,c, Renner and Huntington 2014).

Fig. 1. Map of the eastern Bering Sea, with locations mentioned in the text.

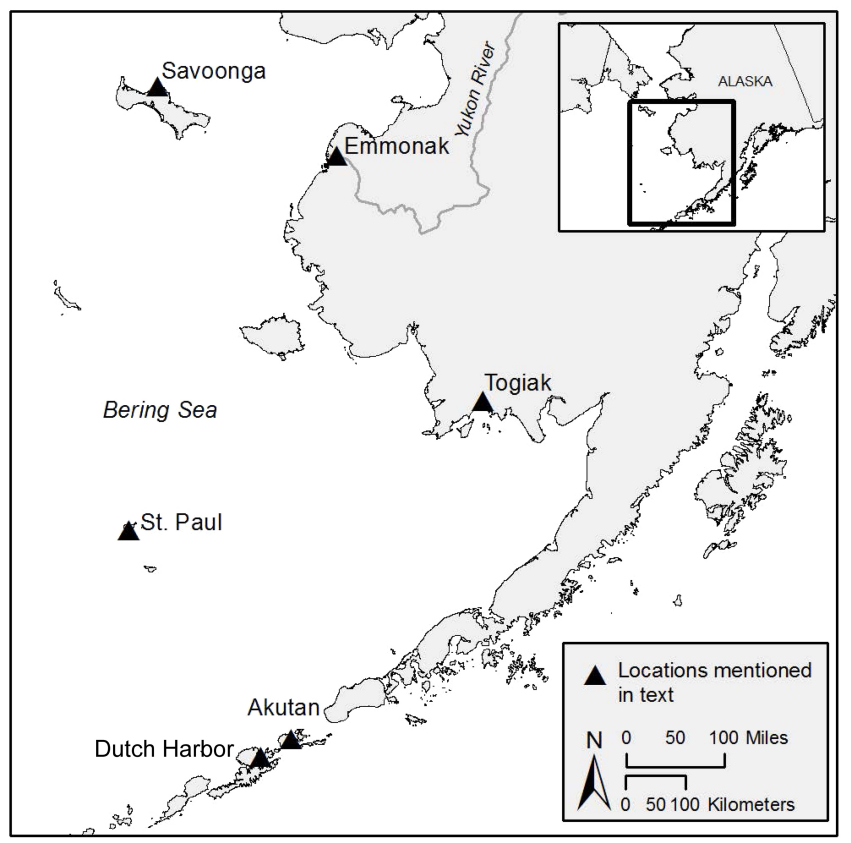

We begin with an overview of the portion of the Bering Sea Project that examined human interactions with the Bering Sea ecosystem. We then review the tangible connections between humans and the ecosystem that our research documented. Next, we show the ways in which human outcomes diverged from the expected response to ecosystem change. We then explore potential social factors that may explain that divergence. Finally, we offer a new conceptual model for studies of human-ecosystem connections and ideas for focusing such research, followed by a conclusion.

\section{THE BERING SEA PROJECT'S MULTIDISCIPLINARY CONCEPTUAL MODEL AND HYPOTHESES}

The Bering Sea Project was a large, five-year study funded by the U.S. National Science Foundation and the North Pacific Research Board, focusing primarily on the southeastern Bering Sea (Wiese et al. 2012). It involved $>100$ researchers examining the Bering Sea ecosystem from the climate through the food web to humans, including our components (Fig. 2). Five overarching hypotheses were developed at the onset of the project by a small group of scientists working with the funding agencies. These hypotheses guided the field studies and modeling (NPRB 2014). In particular, project hypothesis 5 addressed the connections from the ecosystem to humans:

Climate-ocean conditions will change and thus affect the abundance and distribution of commercial and subsistence fisheries. Specifically,
- (a) For commercial fishermen, these changes will lead to a change in home ports and distribution of fishing vessel rents, vessels traveling further and incurring greater fuel costs and peril at sea, and greater burden on smaller vessels.

- (b) For subsistence users, these changes will lead to greater reliance on owners of larger vessels that can travel farther to harvest and distribute subsistence goods, decreased consumption of species with decreased local abundance, and adoption of new species into the diet as these species colonize local areas.

- (c) Current management strategies for fish, seabirds, and marine mammals in the Bering Sea are robust to climate scenarios (range of frequencies of cold and warm years) and associated range of trophic relationships and spatial redistribution.

Fig. 2. Bering Sea Integrated Ecosystem Research Program (BSIERP) conceptual model. NPZ = nutrients, phytoplankton, zooplankton. Lines represent connections, arrows represent directions of influence.

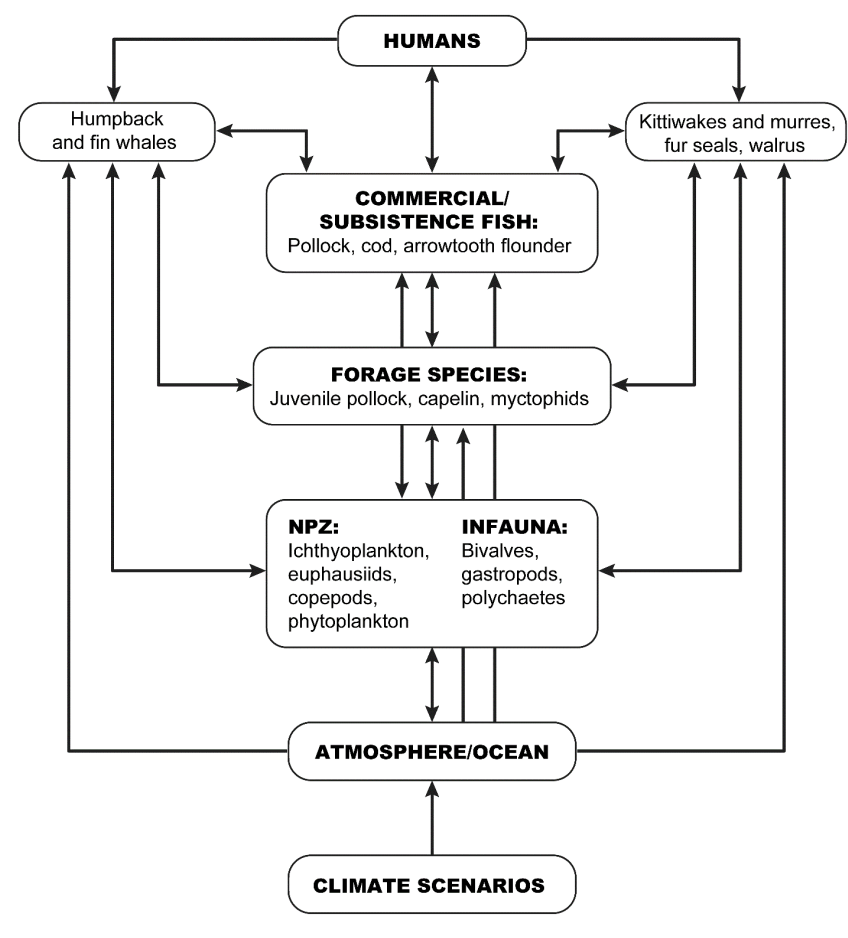

The implications of (a) and (b) are that commercial and subsistence communities and patterns will change in response to changes in the ecosystem (i.e., there will be reasonably tight coupling). The implication of (c) is that our awareness of these ecosystem-human interactions allows us to develop robust management strategies (i.e., that understanding the ecosystem is the key to good management). The conceptual model from the 
Table 1. Brief description of publications that form the basis of the current analysis.

\begin{tabular}{|c|c|c|}
\hline Publication & Connection $^{\dagger}$ & Mitigating factor(s) \\
\hline Haynie and Pfeiffer (2013) & Pollock & $\begin{array}{l}\text { Prices mitigate downturns in stock to reduce } \\
\text { economic impact }\end{array}$ \\
\hline Pfeiffer and Haynie (2012) & Pollock and ice cover & Changing ice and prices of different fish interact \\
\hline Haynie et al. (2014) & Cod and water temperature & $\begin{array}{l}\text { Vessels adjust movement and gear behavior to } \\
\text { adjust to lower catch rates }\end{array}$ \\
\hline Fall et al. (2013) & Subsistence harvest & $\begin{array}{l}\text { Food preference (taste); cost of hunting; ability } \\
\text { to shift harvests }\end{array}$ \\
\hline Huntington et al. (2013a) & Perception of ecosystem health & User conflicts; ability to satisfy demand \\
\hline Huntington et al. (2013b) & Walrus harvest & $\begin{array}{l}\text { Employment patterns; fuel prices; conflicting } \\
\text { activities (e.g., funerals during hunting season) }\end{array}$ \\
\hline
\end{tabular}

Each publication's chief nexus between humans and the ecosystem.

Factors that affect the degree of tight coupling between ecosystem change and human outcome.

project (Fig. 2) reinforces this view, with humans at the end of a chain of bilateral interactions characterizing the ecosystem.

The results of our project components, however, were not consistent with the framework and its underlying expectation of tight coupling between humans and the Bering Sea ecosystem. Our results suggest a system in which ecosystem-human connections are strong: the ecosystem provides a great deal to humans, and humans no doubt exercise considerable influence on the ecosystem. However, the ecosystem and humans are only loosely coupled: human outcomes do not always change notably or quickly as a result of ecosystem changes. This observation is our starting point here. We provide a list of the publications from our project components that form the foundation for the current work, along with the connections and mitigating factors they describe (Table 1).

\section{Ecosystem-human connections}

The most direct connection between Bering Sea ecology and Bering Sea societies is the use of living resources from the Bering Sea ecosystem. As has been well documented, humans harvest a vast quantity of fish and substantial (though considerably lesser) quantities of marine mammals and seabirds in the region (Table 2), producing economic, cultural, intellectual, and spiritual connections between people and the sea (Fall et al. 2013, Fissel et al. 2015).

Table 2. Examples of subsistence harvests from the eastern Bering Sea.

\begin{tabular}{lccc}
\hline \hline Community & Year & Population & $\mathrm{kg} /$ capita $^{\dagger}$ \\
\hline Akutan & 2008 & 81 & 148 \\
Emmonak & 2008 & 788 & 218 \\
Savoonga & 2009 & 695 & 403 \\
Togiak & 2008 & 801 & 137 \\
\hline
\end{tabular}

In the study communities (Fall et al. 2013).

Commercial fisheries harvest approximately 2 million metric tons (t) of fish from the Bering Sea each year. This harvest consists of groundfish caught at sea and delivered primarily to Dutch Harbor and Akutan, crab harvested throughout the region, and salmon caught in Bristol Bay near the Alaska Peninsula and in rivers throughout western Alaska. Very different types of vessels are involved in Alaskan commercial fishing, from small vessels with one or several fishers to large catcher processors with $>100$ people fishing and processing fish at sea (NPFMC 2012). Bering Sea pollock is the largest fishery in the United States by volume, with Bering Sea pollock accounting for $35 \%$ of the U.S. catch in 2014 (Fissel et al. 2015, NMFS 2015), and is currently the largest whitefish and second largest fishery in the world (FAO 2014). Pacific cod is the second most-caught groundfish species in the Bering Sea and Alaska as a whole. The commercial fisheries component of the Bering Sea Project focused on the pollock and Pacific cod catcher processor fisheries. These vessels are distinct fleets that are focused primarily on these species and catch approximately one-half of the pollock and Pacific cod caught in the Bering Sea.

Subsistence harvests by the dozens of predominantly Alaska Native communities on the coast and islands of the Bering Sea produce up to hundreds of kilograms of food per capita, using a wide variety of species, and benefiting nearly all of the residents of most coastal communities (Fall et al. 2013). These harvests were the sole source of food for local inhabitants for millennia (e.g., Dumond and Damas 1984, Fitzhugh and Crowell 1988), and today, remain important sources of nutrition and cultural well-being (e.g., Wolfe 2004).

As shown by the LTK component of the project, subsistence harvests take place over large areas with large variations in distances traveled (Huntington et al. 2013c), despite the high cost of traveling in small boats, indicating a spatially broad engagement with the ecosystem as well as a need for flexibility in harvest areas and species to compensate for the variability in the ecosystem and access to it. These areas shift by season and by year, and cumulatively can cover thousands of squarekilometers. One can extend this analysis further, looking not just at where hunting and fishing take place, but at the areas used by the fish and animals that are harvested. A first look at these "calorie-sheds" (Huntington et al. 2013c) shows just how extensive these areas can be. The calorie-shed for Savoonga, Alaska extends from the Gulf of Alaska through the Bering and Chukchi Seas into the Beaufort Sea, indicating direct material ties to the ecology of a vast region.

In addition to material connections, Bering Sea residents demonstrate a strong intellectual connection to their ecosystem through the depth of their local and traditional knowledge 
(Huntington et al. 2013a). With this knowledge, gained from personal experience and combined with that shared by others and passed down through generations (e.g., Huntington 1998, Berkes 1999), Bering Sea hunters and fishers provided wide-ranging insights into the behavior and trends of individual species, as well as the interactions among species and between biota and physical conditions.

\section{Ecosystem-human coupling}

Recognizing the tangible connections between hunters and fishers and the Bering Sea ecosystem, our project components explored how people responded to ecosystem change and examined the manner in which human outcomes are coupled to ecosystem conditions. The expected coupling includes the impacts anticipated by the previously listed hypotheses. There is ample scientific evidence of changes that have already occurred in the physical and biological systems of the region (e.g., NRC 1996, Hunt et al. 2002, Mueter and Litzow 2008, Stabeno et al. 2012), consistent with traditional knowledge (Huntington et al. 2013a). There is frequent speculation about the implications of this type of change for both commercial fisheries and subsistence practices in the region, nearly all predicting a range of negative effects from reduced harvests (e.g., Ianelli et al. 2011) to higher costs and risks from traveling further or fishing longer (e.g., Cochran et al. 2013), and even substantial outmigration from the region (e.g., Bronen 2011). This narrative, featuring responsive coupling and rapid, often negative effects, does not readily explain what we documented in the Bering Sea.

The summer pollock fishery has displayed a movement northward, but surprisingly, this is correlated with colder temperatures later in the 2000s rather than with annual warmer temperatures (Haynie and Pfeiffer 2013), thus moving in the opposite direction to what might be expected on ecological grounds. The winter fishery has not displayed significant spatial shifts in the fishing grounds, largely because the location of spawning grounds has remained relatively constant and the fishery targets valuable roe-bearing fish in the southeastern Bering Sea.

The Pacific cod longline fishery participants also fish in both the winter and summer. Because Pacific cod avoid cold water, the presence of cold water will concentrate fish in a narrow band further north along the Bering Sea shelf (Haynie et al. 2014). Thus, there is more fishing in the north in colder winters, also contrary to the expected narrative that warmer water will cause fisheries worldwide to shift poleward with shifting fish populations (e.g., Cheung et al. 2010), and contrary to evidence of mean fish population movement in the Bering Sea (Mueter and Litzow 2008).

The effect of sea ice on fishing behavior was also examined in one study of the commercial pollock fishery (Pfeiffer and Haynie 2012). There is significant variation from year to year in how much of the eastern Bering Sea is available to the fishery because of the presence of sea ice on the fishing grounds. The authors found that the increase in open water in winters with low-ice conditions did not significantly alter where the fishery was executed. Because of the significantly higher values of roe-bearing fish in the south, the change in ice cover did not translate into a large change in the location of the winter fishery. Over a longer term, there may be other changes that will lead to a shift in the winter fishery, but there is not currently evidence that increased warming and declining sea ice will significantly shift the location of the fishery.

Across a longer time frame, ocean conditions, fish abundance, fish and fuel prices, and regulations all interact to affect vessel behavior. A wide breadth of empirical evidence indicates that fishers generally adapt their behavior in light of changes to attempt to maximize profits, although vessels may also fish until they reach a desired revenue target or until other noneconomic goals have been met (Camerer 1998, Roy 1998, Holland 2008). Thus, the size and location of fish are important, but this is a function of both the environmental conditions that enable fish to flourish and the economy and human environment that create value in the fish and protect the fishery from overexploitation. Vessels are making large adjustments in fishing locations in reaction to changing spatial abundance in the summer pollock fishery, but value is dominating quantity in the winter fishery, and vessels are consistently concentrated in areas with valuable roebearing fish. Catch shares are also significantly affecting the fish products that vessels produce, which in turn affects the value of catching different sized fish (e.g., Morrison Paul et al. 2009, Haynie and Pfeiffer 2012, 2013, Haynie et al. 2014).

In subsistence communities that were part of this project, there was an apparent disconnect between how people described the health of the Bering Sea ecosystem and the level of subsistence harvests and sharing. For example, Togiak residents described an ecosystem in trouble, with declines of many species and shifts in distribution caused by changing winter sea ice (Huntington et al. 2013a). These observations are consistent with rapid change in the winter marginal ice zone of the Bering Sea (e.g., Mueter and Litzow 2008, Stabeno et al. 2012). Residents of Akutan, in contrast, reported that the ecosystem seemed to be largely stable, with generally adequate conditions and productivity (Huntington et al. 2013a). Subsistence harvest data from Togiak in 1999 and 2008 showed a substantial increase in the total harvest (from 111 to $137 \mathrm{~kg} /$ capita), and an increase in the proportion of households using nearly all major subsistence resources. Akutan, by contrast, had seen a large decrease in subsistence harvest between 1990 and 2008 (from 209 to $148 \mathrm{~kg} /$ capita), and a decrease in the proportion of households using all major subsistence resources (Fall et al. 2013). In other words, what residents described as a poor ecosystem yielded higher harvests for Togiak, whereas what residents described as a stable ecosystem yielded lower harvests for Akutan. It appears that subsistence harvest patterns do not neatly track the described health of the ecosystem in either location.

The declining harvest of northern fur seals (Callorhinus ursinus) on St. Paul Island (Fall et al. 2013) appears to correspond to a decrease in the fur seal population in the Bering Sea (Allen and Angliss 2013), which would offer some evidence of a societal response to ecosystem conditions. Upon closer inspection, however, the connection disappears. The harvest is fewer than 1000 animals, whereas the population is estimated at $>600,000$. The fur seals continue to come ashore in large numbers on St. Paul, so access to fur seals is not a limitation. Instead, the harvest trend is more likely a product of changing food preferences among islanders than a response to a changing ecosystem (Lestenkof et al. 2010). This weaker connection is consistent with previous research on the connection between the two Pribilof Island 
communities of St. Paul and St. George and the Bering Sea ecosystem (Huntington et al. 2009).

Another Bering Sea Project analysis looked at the influence of sea ice and wind conditions on walrus harvests on St. Lawrence Island (Huntington et al. 2013b), which biologists and hunters both reported as major influences on walrus hunting success. Based on local observations about sea ice formation and break-up, and using daily records of walrus hunting effort and success from the U.S. Fish and Wildlife Service, the analysis generated a statistical model for the relationship between wind, sea ice, and hunting outcomes. The result explained only $18-23 \%$ of the variability in hunting success from day to day. While it is possible that more locally precise wind and ice data would have helped increase the model's predictive ability, it is also likely that a great deal of the variability stems from other factors. These factors may include the local distribution and abundance of walrus, but likely also involve employment patterns, community events, fuel prices, and other economic and societal variables.

In short, a wide range of societal factors appear to mediate the connections between the Bering Sea ecosystem and humans, such that human patterns do not necessarily respond clearly or quickly to ecosystem changes or in the expected direction of change. In other words, despite strong connections in the form of subsistence production and commercial fisheries, there does not appear to be much evidence of tight coupling between the ecosystem and humans.

\section{MEDIATING FACTORS IN THE INFLUENCE OF THE ECOSYSTEM ON HUMANS}

The lack of tight coupling described above has several potential explanations, including one or more of the following. (1) Ecosystem conditions may have remained within the bounds of human adjustment over the past two to three decades, in contrast to experiencing a major shift, regime change, or tipping point (e.g., Möllmann et al. 2015). (2) Multiple ecosystem-human connections may reduce the effect of a change in any one connection if other connections are able to compensate (note that this also implies that slow change to a portion of the ecosystem may only slowly become apparent). (3) Factors outside the ecosystem itself may influence the human system, potentially diluting (or alternatively exacerbating) the effect of ecosystem changes. (4) In the case of fisheries, rapidly changing policies (e.g., catch shares) or markets may overwhelm the scale of the effect of gradual environmental change. Our results illustrate aspects of all of these explanations.

In Bering Sea commercial fisheries, all four of the above explanations help to explain what we have observed. Vessels have persisted in the fishery (explanation 1 above), and total catch and revenue from Bering Sea fisheries have been consistently high (Fissel et al. 2015). While the pollock fishery is more specialized than others, there is compensation across species among fisheries (explanation 2) so that diversification increases net revenues and reduces variability (Kasperski and Holland 2013). Interconnected world markets mean that when catch goes down, prices are more likely to be higher (explanation 3 ), all other factors being equal. In many ways, explanation 4 is supported by the fact that the "regime change" in recent decades in the Bering Sea pollock fishery was not environmental change, but the passage of the American Fisheries Act in 1998, which ended the race for fish in 1999 and 2000 (e.g., Holland 2000, Wilen and Richardson 2008). As well as changing environmental conditions, different management actions interact to affect how fisheries are conducted (e.g., Haynie 2014). Similarly, Amendment 80 of the North Pacific Groundfish Management Plan transformed how the non-pollock groundfish trawl fishery has targeted different species (Abbott et al. 2015).

Fisheries management plays a major role in shaping the ways in which fishers interact with the ecosystem and thus the human outcomes of those interactions (explanation 4). The management of commercial fishing in the Bering Sea is extremely complex. Federal groundfish fisheries are managed by the North Pacific Fishery Management Council (NPFMC) and National Marine Fisheries Service, salmon harvest is managed by the State of Alaska's Board of Fish and the Alaska Department of Fish and Game, and several international treaties are also in effect. Commercial halibut harvest is managed by the International Pacific Halibut Commission, but allocation to recreational fisheries and the amount of prohibited species catch that can be taken in other fisheries is determined by the NPFMC. Other agreements are in place to manage overlapping stocks (e.g., fishing in the international "Donut Hole," salmon catch in the high seas). Commercial fish harvesting affects numerous marine mammal species, including the Steller sea lion (Eumetopias jubatus), which has presented challenging trade-offs for managers (e.g., Sanchirico et al. 2013, NMFS 2014).

For Federal groundfish fisheries, the amount of fish that can be caught for different species is dictated by conservative harvest protections that reduce fishing pressure as survey estimates and statistical models indicate that a population is declining. The Bering Sea/Aleutian Islands (BSAI) groundfish fishery is subject to a 2 million $t$ "ecosystem" cap that commonly constrains the total groundfish catch well below the harvest that would be allowed under the already conservative individual species restrictions. The NPFMC therefore considers economic and community factors in recommending harvest levels, although attention to the biological parameters of each species greatly reduces the possibility that fishing pressure threatens biological sustainability.

Another key element in modern fisheries management is the creation of catch share programs, so that a biologically sustainable quota is allocated among individuals or groups who have exclusive claim over the resource. In the Bering Sea, catch shares (e.g., Brinson and Thunberg 2013) were implemented in the pollock component of the Community Development Quota (CDQ) Program in 1992, in halibut and sablefish in 1995, in pollock in 1999 and 2000 through the American Fisheries Act, in the BSAI crab fisheries in 2005, in the BSAI non-pollock "Amendment 80" multispecies trawl fleet in 2008, and for Chinook bycatch in the Bering Sea pollock fishery in 2011. The Pacific cod longline fishery also functions as a cooperative, and the CDQ Program has been greatly expanded. These changes in management have had a number of impacts, generally ending the "race for fish" and providing greater flexibility to the harvester in product form (e. g., fresh instead of frozen) and the timing and location of fishing. This has led to greater value, lower discards, and a range of economic, biological, and safety benefits in most fisheries, although in some cases, a smaller number of fishers have fished a larger share of the fishing quota (e.g., Brinson and Thunberg 2013).

In the BSAI Amendment 80 fishery, the creation of cooperatives in 2008 led to a variety of benefits: lower discards, greater product 
recovery, higher revenues, and lower bycatch. To avoid being closed out of fishing grounds when individual bycatch limits were reached, vessels were able to change their fishing strategies along several axes to catch a greater amount of target catch and a lower amount of bycatch (Abbott et al. 2015). Specifically, vessels adjusted where they fished, moved more in response to large bycatch events, and fished less at night, when bycatch rates are higher. However, at the same time Amendment 80 was implemented, the sector's share of the Pacific cod total allowable catch was reduced significantly. This has led to vessel captains avoiding high cod catch rates to ensure that they are able to continue to catch their share of other species such as yellowfin sole (Limanda aspera) and rock sole (Lepidopsetta polyxystra) throughout the year. These changes illustrate how the catch share management structure has allowed the fishery to increase benefits greatly, and individual fishers have been able to adapt creatively to the changes in species allocations and fishing conditions that they face. Our findings are consistent across a diverse range of fisheries in which catch shares have been implemented (e.g., Costello et al. 2008, Brinson and Thunburg 2013), although the distribution of economic benefits and the nature of communities have also been affected, and challenges and concern remain for effective implementation (e.g., Copes 1986, Bromley 2009, Criddle and Strong 2013, Carothers 2015).

The comparison of harvest patterns over time in Akutan, Emmonak, and Togiak reveals some shifts in relative harvest levels, but also a high degree of consistency over time (Fall et al. 2013). For the period of 1989-2011, the walrus harvest in Savoonga ranged from 148 animals in 1994 to 849 animals in 2000, with an average of 457 animals (Fall et al. 2013), indicating great variability but also an ability to persist over time, likely as a result of harvesters compensating with other species in poor walrus hunting years. In these cases, ecosystem conditions appear to have remained within the range of human flexibility (explanation 1 above), and the use of many species harvested over large areas and at different times of year (explanation 2) has likely contributed to the ability to produce sufficient food each year, though in a varying mix of species.

Examining changes over time and potential ecosystem influences on subsistence revealed the influence of other factors as well (explanation 3). For example, in Emmonak, Fienup-Riordan et al. (2013) used ethnographic methods to document a history of natural-social interactions, which they were able to combine with the results of previous research, for example, documenting seal hunting areas in 1980. They found large changes in human behavior, including a shrinking hunting area as more powerful snowmobiles allowed hunters to make day trips instead of camping trips and changing ice conditions made camping on sea ice riskier and thus less attractive. The idea that improved technology would contribute to a reduced use area is counter to expectations. The authors concluded that the social context is an essential component of understanding change to ecosystemhuman interactions.

Similarly, reports of worse spring weather and faster break-up of sea ice suggest that the number of suitable days for walrus hunting around Savoonga may be decreasing. There are many physical and biological variables involved in hunting success, and the inability of Huntington et al. (2013b) to explain much of the hunting variability by considering wind and ice conditions must be considered in that light. Favorable conditions provide only the opportunity. The ability to purchase fuel when needed; good health for oneself, one's crew, and one's family; the ability to get time off of work; and other constraints must all be resolved before hunting can be attempted. Effort appears to have the largest influence on success.

In the case of Togiak and the apparent divergence between perception of the ecosystem and subsistence productivity, interviews with local residents shed some light on potential explanations. At the time of the interviews, Togiak residents were concerned about the effects of commercial trawl and other fisheries in their area and may thus have perceived changes in the ecosystem as negative ones stemming from fishing by nonlocals (Huntington et al. 2013a). This is not to say that the ecosystem may not be changing, potentially in predominantly negative ways, but simply that perception may be influenced by expectations or by a desire to attribute effects to a disliked activity or group. In Akutan, change within the community may result in lower subsistence harvests, regardless of the overall health of the ecosystem, similar to the decline in fur seal harvest in St. Paul irrespective of people's ability to harvest fur seals. The quantities of the harvests in Togiak and Akutan remain high, so any decline in demand must be regarded in relative terms and with an expectation of high interannual variability not captured in two data points. Nonetheless, food preferences, fuel costs, employment demands, and other social and economic factors undoubtedly play substantial roles now and will continue to do so in the future.

\section{WHY A BROADER CONCEPTION OF ECOSYSTEM- HUMAN INFLUENCES IS NEEDED}

Ecosystem influences do not readily explain outcomes for commercial fishers or subsistence hunters and fishers in the Bering Sea. Examining only the direct ecosystem-human connections may result in missing many additional influences and thus lead to erroneous interpretations of stasis or change in the interactions that constitute human uses of the ecosystem. For example, stable harvests may reflect the spatial distribution of target species rather than overall abundance, or may reflect improved harvesting methods, masking declines in the populations in question or otherwise obscuring ecosystem-human influences (e.g., Harley et al. 2001, Keane et al. 2011, Crona et al. 2015). Catch quota systems and allocations may work well within the historical range of ecosystem conditions but fail to allow for adjustment if those conditions change dramatically, creating a new vulnerability while not enabling new opportunities. Subsidies of various kinds can sustain communities above and beyond what the ecosystem provides (e.g., Huntington et al. 2009), thereby giving a misleading picture about the ability to withstand environmental change or the importance of the ecosystem to local well-being. At the same time, the role of innovation and flexibility may be overlooked if aggregate outcomes are considered in the absence of fine-scale details.

Future interdisciplinary research on ecosystem-human interactions in the Bering Sea (and perhaps elsewhere) should start with a more detailed and interactive conceptual model of the system (Fig. 3), more similar to SES models (e.g., Bodin and Tengö 2012, Kittinger et al. 2012, McGinnis and Ostrom 2014, 
Bundy et al. 2016) than to the initial model for the Bering Sea Project. Studying these additional influences (within and among the boxes in Fig. 3) offers a means of placing ecosystem influences in context and balancing detailed examinations of the ecosystem with similarly detailed investigation of the social system's influences on human welfare, drawing on the findings of SES practitioners and others. We can also expect that the relative influences among the various factors in the conceptual model will vary over time and by the subsystem being considered (one commercial fishery vs. another, commercial vs. recreational, commercial vs. subsistence, one subsistence community vs. another, etc.).

Fig. 3. New conceptual model for the Bering Sea socialecological system. Solid lines reflect an ecosystem focus of management and management evaluation in light of change. Dashed lines reflect influences and connections outside the ecosystem.

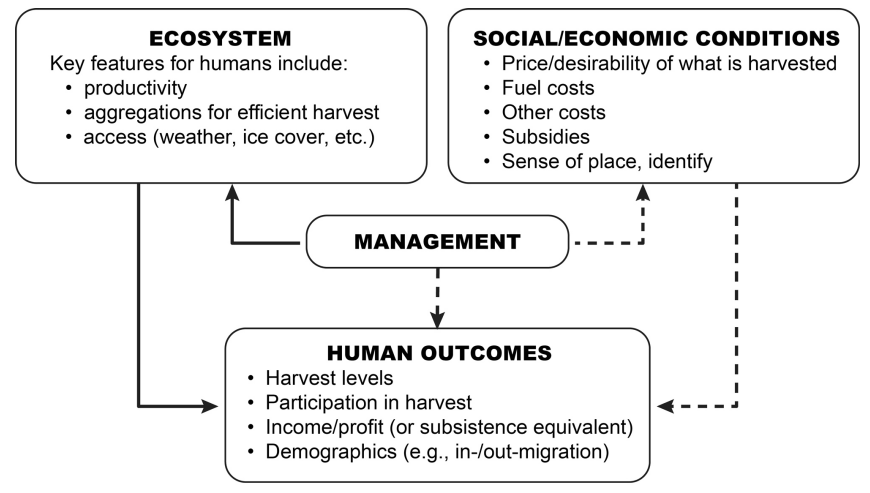

A key element of future interdisciplinary studies should be the clear definition of the human outcome(s) that are to be examined and at what scale the analysis will occur (e.g., Cumming et al. 2006, Perry et al. 2011, Crona et al. 2015). Fine-scale human outcomes (e.g., a fisherman sells his boat, a family moves out of the region) will be far more common than coarse-scale outcomes (e.g., a commercial fishery ends, a community's population changes significantly). Fine-scale human outcomes may shed light on the individual decisions and conditions that lead to coarsescale outcomes (e.g., Huntington et al. 2009), while coarse-scale outcomes may better reflect large-scale trends. Both are relevant, but the focus needs to be defined clearly so that actual correlations can be detected that are consistent with the study design rather than as after-the-fact interpretations.

Another desirable aspect of future studies is a better definition of the time scale to be examined. Over what time scales can we expect to see responses to ecosystem change? There are many mechanisms for smoothing out the influence of a bad year or two, and many influences on human behavior that take time to have an effect. A common statement by commercial fishermen is "every year is different." Just as climate change is difficult to detect in cyclically and randomly varying environmental data, it is challenging for analysts or members of communities to identify clear changes in their ever-varying environment, much less the various causes of the changes they do see.

Ecosystem studies, insofar as they connect with human uses of the system, should also focus more specifically on the details of ecosystem influences on people. For example, fishers typically target aggregations of fish and may thus be influenced more by the patterns of aggregation than by average abundance or productivity over the entire fishing grounds. Observations and predictions of general northward movements of fish (e.g., Pinsky et al. 2013, Jones and Cheung 2015) may not offer much insight into what will actually occur with specific fisheries. Understanding the particular details that matter to human uses in a particular region is essential if we are to do more than speak in generalities (Haynie and Pfeiffer 2012).

Finally, the conceptual model points to defining the "system" more broadly. Just as the ecosystem model (Fig. 2) starts with climate, the human model (Fig. 3) needs to include some representation of the wider societal forces that shape the lives and livelihoods of fishers and hunters. Not all factors need be studied with equal emphasis, but it is important to examine potential influences and how they may be changing to understand the role they may play in diluting or concentrating the influences of ecosystem change. Only with such an understanding can we confidently assess the robustness of the harvest and management strategies employed by humans in the Bering Sea.

We suggest that what we found in the Bering Sea may be a relatively common form of human-ecosystem connection and coupling, in contrast to the tight coupling that produces compelling narratives of the welfare of resource users being directly aligned with the health of the environment (e.g., Hamilton et al. 2003, 2004, Voinov et al. 2004). Further work as outlined here, in the Bering Sea and elsewhere, would help determine if this idea is true, perhaps providing more insight into a class of systems with important implications for human behavior and management.

\section{CONCLUSIONS}

The Bering Sea ecosystem provides a great deal to humans. The human influence on the ecosystem and its constituent species is evident in the extent of fisheries and hunting management measures, including ones aimed at conserving food web productivity and function and not just the abundance of a single target species (Ianelli et al. 2011). The Bering Sea Project is but one of many efforts to understand the implications of change for this ecosystem and, by extension and as justification, for the humans who rely on it. A conceptual model that builds an entire ecosystem from climate and nutrients to top consumers, including humans, may be insufficient, however, if the behavior and role of those humans is also being influenced by factors not anticipated by the model or the overall study design. This point is no surprise to those studying SESs, but it needs to be tightly integrated into future interdisciplinary efforts.

This critique is not to downplay the insights that came from the Bering Sea Project as it was conducted. The ecosystem and all the components of the study were encompassed within one conceptual model, providing the framework for connections and synthesis. Annual meetings of all the investigators provided the opportunity for in-depth interactions and learning that was truly interdisciplinary. Many interesting discussions arose, some of which developed into papers that were not anticipated at the project's start (e.g., Ianelli et al. 2011, Huntington et al. 2013b, Renner and Huntington 2014). A great deal was learned about many aspects of the ecosystem, including a reinforcement of the idea that the social and economic realms overlap the natural realm but do not fall entirely within it. Humans are affected by other 
things, and have the ability to adjust their behavior to mitigate (or exacerbate) the effects of change, be they due to climate or other factors.

When this aforementioned insight became apparent, the study was far enough along that broadening the scope of inquiry was not practical. The research efforts already underway had to be completed to fulfill the responsibilities of each project component. It took several years of experience with different LTK, economic, physical, and biological components of the project to grasp fully the subtle interactions among (or even within) the various project components. Leaving more room to pursue new directions of research mid-project is difficult for many reasons, but worth pursuing in future large-scale, complex projects in which the key findings and even the broad directions of relevant research may not be apparent at the beginning. Expecting or allowing project hypotheses to be reconstituted on an annual basis perhaps would allow greater flexibility in the evolution of the project.

Regarding natural-social connections specifically, we have presented some ideas for future studies (see Why a broader conception of ecosystem-human influences is needed). The social realm likely cannot be encompassed within just one or two project components or research efforts, but requires a breadth of expertise and the ability to explore the range of factors that our proposed conceptual model attempts to capture. In addition, there needs to be time and space to join researchers in both the social and natural sciences in exploring the nature and extent of those connections between the ecosystem and the humans who use it. The multiyear nature of the Bering Sea project was fantastic in this regard, but more resources could be focused productively on examining how the complex social systems that are partly outlined here interact with various facets of the ecosystem. Each fishery has its own sets of rules and economic, biological, and cultural constraints. Integrating the output from economic, community, and LTK studies with ecosystem analyses will improve the ability to use the new understanding of social and economic systems in better managing the natural resources that humans use from the Bering Sea.

Even ecosystems as intensively used as the Bering Sea are not necessarily tightly coupled with the humans who use them. Ecosystem-human connections are not static or mechanical ones dependent only on the mode of connection, but are influenced, and at times dominated, by societal conditions and dynamics. Thus, more research is needed to examine these types of cases in which connections exist but social influences are also crucial determinants of human outcomes. From a policy perspective, a key question is how management can foster an effective response to change, even if that change is strongly detrimental. Such a research emphasis will help avoid erroneous predictions of rapid societal demise following natural-system change, and instead allow us to understand and make use of the myriad ways in which society and the natural world buffer themselves from the influence of one another.

In some sense, the idea that social dynamics have a substantial effect on human well-being is a hopeful result in the context of climate change that is beyond the control of Alaska communities and resource managers. By understanding the priorities of people and communities in a changing ecosystem, managers have an opportunity to improve human welfare, even as the environment may change and some traditionally beneficial uses may decline or disappear.

Responses to this article can be read online at: http://www.ecologyandsociety.org/issues/responses. $\mathrm{php} / 8729$

\section{Acknowledgments:}

We thank the North Pacific Research Board for funding our Bering Sea Project studies and for supporting HPH in the writing of this paper. We thank our Bering Sea Project colleagues for their contributions to the research on which this paper is based. We thank Tom Van Pelt, Mike Sigler, Ron Felthoven, and Amber HimesCornell for their constructive comments on a draft of this manuscript, and we thank Danielle Dickson and Rebecca White for help with the figures. This paper is BEST/BSIERP Bering Sea Project publication number 181 and NPRB publication number 609.

\section{LITERATURE CITED}

Abbott, J. K., A. C. Haynie, and M. N. Reimer. 2015. Hidden flexibility: institutions, incentives, and the margins of selectivity in fishing. Land Economics 91(1):169-195. http://dx.doi. org/10.3368/le.91.1.169

Alberti, M., H. Asbjornsen, L. A. Baker, N. Brozovic, L. E. Drinkwater, S. A. Drzyzga, C. A. Jantz, J. Fragoso, D. S. Holland, T. A. Kohler, J. Liu, W. J. McConnell, H. D. G. Maschner, J. D. A. Millington, M. Monticino, G. Podestá, R. G. Pontius, C. L. Redman, N. J. Reo, D. Sailor, and G. Urquhart. 2011. Research on coupled human and natural systems (CHANS): approach, challenges, and strategies. Bulletin of the Ecological Society of America 92(2):218-228. http://dx.doi.org/10.1890/0012-9623-92.2.218

Allen, B. M., and R. P. Angliss. 2013. Northern fur seal (Callorhinus ursinus): eastern Pacific stock. NOAA-TMAFSC-277. Alaska Marine Mammal Stock Assessments, National Oceanic and Atmospheric Administration, Silver Spring, Maryland, USA. [online] URL: http://www.nmfs.noaa. gov/pr/sars/2013/ak2013 northernfurseal-ep.pdf

Berkes, F. 1999. Sacred ecology: traditional ecological knowledge and resource management. Taylor and Francis, Philadelphia, Pennsylvania, USA.

Bodin, Ö., and M. Tengö. 2012. Disentangling intangible socialecological systems. Global Environmental Change 22(2):430-439. http://dx.doi.org/10.1016/j.gloenvcha.2012.01.005

Brinson, A. A., and E. M. Thunberg. 2013. The economic performance of U.S. catch share programs. NOAA Technical Memorandum NMFS-F/SPO-133. National Oceanic and Atmospheric Administration, Silver Spring, Maryland, USA. [online] URL: https://www.st.nmfs.noaa.gov/Assets/economics/ catch-shares/documents/Catch Shares Report FINAL.pdf

Bromley, D. W. 2009. Abdicating responsibility: the deceits of fisheries policy. Fisheries 34(6):280-302. http://dx.doi.

org/10.1577/1548-8446-34.6.280 
Bronen, R. 2011. Climate-induced community relocations: creating an adaptive governance framework based in human rights doctrine. N.Y.U. Review of Law and Social Change 35 (2):356-406.

Bundy, A., R. Chuenpagdee, S. R. Cooley, O. Defeo, B. Glaeser, P. Guillotreau, M. Isaacs, M. Mitsutaku, and R. I. Perry. 2016. A decision support tool for response to global change in marine systems: the IMBER-ADApT framework. Fish and Fisheries, in press. http://dx.doi.org/10.1111/faf.12110

Camerer, C. 1998. Bounded rationality in individual decision making. Experimental Econonomics 1(2):163-183. http://dx.doi. org/10.1023/A:1009944326196

Carothers, C. 2015. Fisheries privatization, social transitions, and well-being in Kodiak, Alaska. Marine Policy 61:313-322. http:// dx.doi.org/10.1016/j.marpol.2014.11.019

Cheung, W. W. L., V. W. Y. Lam, J. L. Sarmiento, K. Kearney, R. Watson, D. Zeller, and D. Pauly. 2010. Large-scale redistribution of maximum fisheries catch potential in the global ocean under climate change. Global Change Biology 16(1):24-35. http://dx.doi. org/10.1111/j.1365-2486.2009.01995.X

Cochran, P., O. H. Huntington, C. Pungowiyi, S. Tom, F. S. Chapin III, H. P. Huntington, N. G. Maynard, and S. F. Trainor. 2013. Indigenous frameworks for observing and responding to climate change in Alaska. Climatic Change 120(3):557-567. http:// dx.doi.org/10.1007/s10584-013-0735-2

Copes, P. 1986. A critical review of the individual quota as a device in fisheries management. Land Economics 62(3):278-291. http:// dx.doi.org/10.2307/3146392

Costello, C., S. D. Gaines, and J. Lynham. 2008. Can catch shares prevent fisheries collapse? Science 321:1678-1681. http://dx.doi. org $/ 10.1126 /$ science 1159478

Criddle, K. R., and J. Strong. 2013. Dysfunction by design: consequences of limitations on transferability of catch shares in the Alaska pollock fishery. Marine Policy 40:91-99. http://dx.doi. org/10.1016/j.marpol.2013.01.006

Crona, B. I., T. M. Daw, W. Swartz, A. V. Norström, M. Nyström, M. Thyresson, C. Folke, J. Hentati-Sundberg, H. Österblom, L. Deutsch, and M. Troell. 2016. Masked, diluted and drowned out: how global seafood trade weakens signals from marine ecosystems. Fish and Fisheries, in press. http://dx.doi.org/10.1111/ $\underline{\text { faf.12109 }}$

Crona, B. I., T. Van Holt, M. Petersson, T. M. Daw, and E. Buchary. 2015. Using social-ecological syndromes to understand impacts of international seafood trade on small-scale fisheries. Global Environmental Change 35:162-175. http://dx.doi. org/10.1016/j.gloenvcha.2015.07.006

Cumming, G. S., D. H. M. Cumming, and C. L. Redman. 2006. Scale mismatches in social-ecological systems: causes, consequences, and solutions. Ecology and Society 11(1):14. [online] URL: http://www.ecologyandsociety.org/vol11/iss1/ art14/

Dumond, D. E., and D. Damas. 1984. Prehistory of the Bering Sea region. Smithsonian Institution, Washington, D.C., USA.
Fall, J. A., N. S. Braem, C. L. Brown, L. B. HutchinsonScarbrough, D. S. Koster, and T. M. Krieg. 2013. Continuity and change in subsistence harvests in five Bering Sea communities: Akutan, Emmonak, Savoonga, St. Paul, and Togiak. Deep Sea Research II 94:274-291. http://dx.doi.org/10.1016/j.dsr2.2013.03.010

FAO [Food and Agriculture Organisation]. 2014. The state of world fisheries and aquaculture. FAO, Rome, Italy. [online] URL: http://www.fao.org/3/a-i3720e/index.html

Fienup-Riordan, A., C. Brown, and N. M. Braem. 2013. The value of ethnography in times of change: the story of Emmonak. Deep Sea Research II 94:301-311. http://dx.doi.org/10.1016/j. dsr2.2013.04.005

Fissel, B., M. Dalton, R. Felthoven, B. Garber-Yonts, A. Haynie, A. Himes-Cornell, S. Kasperski, J. Lee, D. Lew, and C. Seung. 2015. Stock assessment and fishery evaluation report for the groundfish fisheries of the Gulf of Alaska and Bering Seal Aleutian Islands area: economic status of the groundfish fisheries off Alaska, 2014. National Oceanic and Atmospheric Administration, Seattle, Washington, USA. [online] URL: http://www.afsc.noaa. gov/REFM/Docs/2015/economic.pdf

Fitzhugh, W. W., and A. Crowell. 1988. Crossroads of continents: cultures of Siberia and Alaska. Smithsonian Institution, Washington, D.C., USA.

Folke, C., S. R. Carpenter, B. Walker, M. Scheffer, T. Chapin, and J. Rockström. 2010. Resilience thinking: integrating resilience, adaptability and transformability. Ecology and Society 15(4):20. [online] URL: http://www.ecologyandsociety.org/voll5/iss4/ $\underline{\operatorname{art} 20 /}$

Hamilton, L. C., B. C. Brown, and R. O. Rasmussen. 2003. West Greenland's cod-to-shrimp transition: local dimensions of climatic change. Arctic 56(3):271-282. http://dx.doi.org/10.14430/ arctic 623

Hamilton, L. C., C. R. Colocousis, and S. T. F. Johansen. 2004. Migration from resource depletion: the case of the Faroe Islands. Society and Natural Resources 17(5):443-453. http://dx.doi. org/10.1080/08941920490430232

Harley, S. J., R. A. Myers, and A. Dunn. 2001. Is catch-per-uniteffort proportional to abundance? Canadian Journal of Fisheries and Aquatic Science 58(9):1760-1772. http://dx.doi.org/10.1139/ f01-112

Haynie, A. C. 2014. Changing usage and value in the western Alaska Community Development Quota (CDQ) program. Fisheries Science 80(2):181-191. http://dx.doi.org/10.1007/ s12562-014-0723-0

Haynie, A. C., and L. Pfeiffer. 2012. Why economics matters for understanding the effects of climate change on fisheries. ICES Journal of Marine Science 69(7):1160-1167. http://dx.doi. org/10.1093/icesjms/fss021

Haynie, A. C., and L. Pfeiffer. 2013. Climatic and economic drivers of the Bering Sea walleye pollock (Theragra chalcogramma) fishery: implications for the future. Canadian Journal of Fisheries and Aquatic Science 70(6):841-853. http://dx. doi.org/10.1139/cjfas-2012-0265 
Haynie, A. C., L. Pfeiffer, and J. Watson. 2014. Spatial economic models of pollock and cod. NPRB BSIERP Project B72 Final Report. North Pacific Research Board, Anchorage, Alaska, USA.

Hentati-Sundberg, J., J. Hjelm, W. J. Boonstra, and H. Österblom. 2015. Management forcing increased specialization in a fishery system. Ecosystems 18(1):45-61. http://dx.doi.org/10.1007/ $\underline{\text { s10021-014-9811-3 }}$

Holland, D. S. 2000. Fencing the fisheries commons: regulatory barbed wire in the Alaskan groundfish fisheries. Marine Resource Economics 15(2):141-149. http://dx.doi.org/10.1086/mre.15.2.42629297

Holland, D. S. 2008. Are fishermen rational? A fishing expedition. Marine Resource Economics 23(3):325-344. http://dx.doi. org/10.1086/mre.23.3.42629621

Hunt, G. L. Jr., P. Stabeno, G. Walters, E. Sinclair, R. D. Brodeur, J. M. Napp, and N. A. Bond. 2002. Climate change and control of the southeastern Bering Sea pelagic ecosystem. Deep Sea Research II 49(26):5821-5853. http://dx.doi.org/10.1016/S0967-0645 (02)00321-1

Huntington, H. P. 1998. Observations on the utility of the semidirective interview for documenting traditional ecological knowledge. Arctic 51(3):237-242. http://dx.doi.org/10.14430/ $\underline{\operatorname{arctic} 1065}$

Huntington, H. P., N. M. Braem, C. L. Brown, E. Hunn, T. M. Krieg, P. Lestenkof, G. Noongwook, J. Sepez, M. F. Sigler, F. K. Wiese, and P. Zavadil. 2013a. Local and traditional knowledge regarding the Bering Sea ecosystem: selected results from five indigenous communities. Deep Sea Research II 94:323-332. http:// dx.doi.org/10.1016/j.dsr2.2013.04.025

Huntington, H. P., L. C. Hamilton, C. Nicolson, R. Brunner, A. Lynch, A. E. J. Ogilvie, and A. Voinov. 2007. Toward understanding the human dimensions of the rapidly changing arctic system: insights and approaches from five HARC projects. Regional Environmental Change 7(4):173-186. http://dx.doi. org/10.1007/s10113-007-0038-0

Huntington, H. P., S. A. Kruse, and A. J. Scholz. 2009. Demographic and environmental conditions are uncoupled in the social-ecological system of the Pribilof Islands. Polar Research 28:119-128. http://dx.doi.org/10.1111/j.1751-8369.2009.00096.x

Huntington, H. P., G. Noongwook, N. A. Bond, B. Benter, J. A. Snyder, and J. Zhang. 2013b. The influence of wind and ice on spring walrus hunting success on St. Lawrence Island, Alaska. Deep Sea Research II 94:312-322. http://dx.doi.org/10.1016/j. $\underline{\mathrm{dsr} 2.2013 .03 .016}$

Huntington, H. P., I. Ortiz, G. Noongwook, M. Fidel, D. Childers, M. Morse, J. Beaty, L. Alessa, and A. Kliskey. 2013c. Mapping human interaction with the Bering Sea ecosystem: comparing seasonal use areas, lifetime use areas, and "calorie-sheds". Deep Sea Research II 94:292-300. http://dx.doi.org/10.1016/j. $\underline{\mathrm{dsr} 2.2013 .03 .015}$

Ianelli, J. N., A. B. Hollowed, A. C. Haynie, F. J. Mueter, and N. A. Bond. 2011. Evaluating management strategies for eastern Bering Sea walleye pollock (Theragra chalcogramma) in a changing environment. ICES Journal of Marine Science 68 (6):1297-1304. http://dx.doi.org/10.1093/icesjms/fsr010
Jones, M. C., and W. W. L. Cheung. 2015. Multi-model ensemble projections of climate change effects on global marine biodiversity. ICES Journal of Marine Science 72(3):741-752. http://dx.doi.org/10.1093/icesjms/fsu172

Kasperski, S., and D. S. Holland. 2013. Income diversification and risk for fishermen. Proceedings of the National Academy of Sciences 110(6):2076-2081. http://dx.doi.org/10.1073/pnas.1212278110

Keane, A., J. P. G. Jones, and E. J. Milner-Gulland. 2011. Encounter data in resource management and ecology: pitfalls and possibilities. Journal of Applied Ecology 48(5):1164-1173. http:// dx.doi.org/10.1111/j.1365-2664.2011.02034.x

Kittinger, J. N., E. M. Finkbeiner, E. W. Glazier, and L. B. Crowder. 2012. Human dimensions of coral reef social-ecological systems. Ecology and Society 17(4):17. http://dx.doi.org/10.5751/ ES-05115-170417

Lestenkof, P. M., P. A. Zavadil, S. M. Zacharof, and E. M. Melovidov. 2010. Subsistence harvest monitoring results from to and local and traditional knowledge interview results for St. Paul Alaska. A report to the North Pacific Research Board Aleut Community of St Paul Island Tribal Government Ecosystem Conservation Office, St. Paul, Alaska, USA.

Levin, P. S., M. J. Fogarty, S. A. Murawski, and D. Fluharty. 2009. Integrated ecosystem assessments: developing the scientific basis for ecosystem-based management of the ocean. Plos Biology 7 (1):e1000014. http://dx.doi.org/10.1371/journal.pbio.1000014

Levin, P. S., C. R. Kelble, R. L. Shuford, C. Ainsworth, Y. deReynier, R. Dunsmore, M. J. Fogarty, K. Holsman, E. A. Howell, M. E. Monaco, S. A. Oakes, and F. Werner. 2014. Guidance for implementing integrated ecosystem assessments : a US perspective. ICES Journal of Marine Science 71(5):1198-1204. http://dx.doi.org/10.1093/icesjms/fst112

Loomis, D. K., and S. K. Paterson. 2014. The human dimensions of coastal ecosystem services: managing for social values. Ecological Indicators 44:6-10. http://dx.doi.org/10.1016/j. ecolind.2013.09.035

Mahon, R., P. McConney, and R. N. Roy. 2008. Governing fisheries as complex adaptive systems. Marine Policy 32 (1):104-112. http://dx.doi.org/10.1016/j.marpol.2007.04.011

McGinnis, M. D., and E. Ostrom. 2014. Social-ecological system framework: initial changes and continuing challenges. Ecology and Society 19(2):30. http://dx.doi.org/10.5751/es-06387-190230

Möllmann, C., C. Folke, M. Edwards, and A. Conversi. 2015. Marine regime shifts around the globe: theory, drivers and impacts. Philosophical Transactions of the Royal Society B 370:20130260. http://dx.doi.org/10.1098/rstb.2013.0260

Morrison Paul, C. J., M. O. Torres, and R. G. Felthoven. 2009. Fishing revenue, productivity and product choice in the Alaskan pollock fishery. Environmental and Resource Economics 44:457. http://dx.doi.org/10.1007/s10640-009-9295-3

Mueter, F. J., and M. A. Litzow. 2008. Sea ice retreat alters the biogeography of the Bering Sea continental shelf. Ecological Applications 18(2):309-320. http://dx.doi.org/10.1890/07-0564.1 
NMFS [National Marine Fisheries Service]. 2014. Final environmental impact statement: Steller sea lion protection measures for groundfish fisheries in the Bering Sea and Aleutian Islands Management Area. NMFS, Juneau, Alaska, USA. [online] URL: https://repository.library.noaa.gov/view/noaa/4905

NMFS [National Marine Fisheries Service]. 2015. Fisheries of the United States, 2014. National Oceanic and Atmospheric Administration, Silver Spring, Maryland, USA. [online] URL: https://www.st.nmfs.noaa.gov/commercial-fisheries/fus/fus14/index

NPFMC [North Pacific Fishery Management Council]. 2012. Fishing fleet profiles. NPFMC, Anchorage, Alaska, USA. http:// www.npfmc.org/wp-content/PDFdocuments/resources/FleetProfiles412. pdf

NPRB [North Pacific Research Board]. 2014. BSIERP conceptual framework. NPRB, Anchorage, Alaska, USA. http://www.nprb. org/assets/uploads/files/BSIERP/BSIERP_Conceptual_Framework Hypotheses.pdf

NRC [National Research Council]. 1996. The Bering Sea ecosystem. National Academies Press, Washington, D.C., USA.

Perry, R. I., R. E. Ommer, M. Barange, S. Jentoft, B. Neis, and U. R. Sumaila. 2011. Marine social-ecological responses to environmental change and the impacts of globalization. Fish and Fisheries 12(4):427-450. http://dx.doi.org/10.1111/j.1467-2979.2010.00402. $\underline{\mathrm{x}}$

Pfeiffer, L., and A. C. Haynie. 2012. The effect of decreasing seasonal sea-ice cover on the winter Bering Sea pollock fishery. ICES Journal of Marine Science 69(7):1148-1159. http://dx.doi. org/10.1093/icesims/fss097

Pinsky, M. L., B. Worm, M. J. Fogarty, J. L. Sarmiento, and S. A. Levin. 2013. Marine taxa track local climate velocities. Science 341:1239-1242. http://dx.doi.org/10.1126/science.1239352

Renner, M., and H. P. Huntington. 2014. Connecting subsistence harvest and marine ecology: a cluster analysis of communities by fishing and hunting patterns. Deep Sea Research II 109:293-299. http://dx.doi.org/10.1016/j.dsr2.2014.03.005

Rochet, M.-J., F. Daurès, and V. M. Trenkel. 2012. Capacity management, not stock status or economics, drives fleet dynamics in the Bay of Biscay ecosystem on a decadal time scale. Canadian Journal of Fisheries and Aquatic Sciences 69(4):695-710. http:// dx.doi.org/10.1139/f2012-002

Roy, N. 1998. Fishing behavior and the length of the fishing season. Marine Resource Economics 13(3):197-213. http://dx.doi. org/10.1086/mre.13.3.42629234

Sanchirico, J. N., D. K. Lew, A. C. Haynie, D. M. Kling, and D. F. Layton. 2013. Conservation values in marine ecosystem-based management. Marine Policy 38:523-530. http://dx.doi.org/10.1016/ j.marpol.2012.08.008

Stabeno, P. J., E. V. Farley Jr., N. B. Kachel, S. Moore, C. W. Mordy, J. M. Napp, J. E. Overland, A. I. Pinchuk, and M. F. Sigler. 2012. A comparison of the physics of the northern and southern shelves of the eastern Bering Sea and some implications for the ecosystem. Deep Sea Research II 65-70:14-30. http://dx.doi. org/10.1016/j.dsr2.2012.02.019
Voinov, A., L. Bromley, E. Kirk, A. Korchak, J. Farley, T. Moiseenko, T. Krasovskaya, Z. Makarova, V. Megorski, V. Selin, G. Kharitonova, and R. Edson. 2004. Understanding human and ecosystem dynamics in the Kola Arctic: a participatory integrated study. Arctic 57(4):375-388. http://dx.doi.org/10.14430/arctic515

Wiese, F. K., W. J. Wiseman Jr., and T. I. Van Pelt. 2012. Bering Sea linkages. Deep Sea Research II 65-70:2-5. http://dx.doi. org/10.1016/j.dsr2.2012.03.001

Wilen, J. E., and E. J. Richardson. 2008. Rent generation in the Alaskan pollock conservation cooperative. Pages 361-368 in R. Townsend, R. Shotton, and H. Uchida, editors. Case studies in fisheries self-governance. FAO Fisheries Technical Paper 504. Food and Agriculture Organisation, Rome, Italy. http://www.fao. org/3/a-a1497e/a1497e31.pdf

Wolfe, R. J. 2004. Local traditions and subsistence: a synopsis from twenty-five years of research by the State of Alaska. Technical Paper 284. Alaska Department of Fish and Game, Division of Subsistence, Juneau, Alaska, USA. [online] URL: http://www. adfg.alaska.gov/techpap/tp284.pdf 